\title{
MEMANTAPKAN LANDASAN HUKUM FORMIL SEBAGAI ALAT SINGKRONISASI DAN HARMONISASI PERATURAN PERUNDANG - UNDANGAN
}

\author{
Insan Tajali Nur \\ Insan.tn@gmail.com \\ Fakultas Hukum Universitas Mulawarman Samarinda
}

\begin{abstract}
ABSTRAK
Pengaturan dalam Perda dihadapkan pada persoalan bagaimana agar Perda dapat mengatur urusan kewenangan sesuai dengan karakteristik daerahnya. Namun tidak bertentangan dengan peraturan perundang-undangan yang lebih tinggi. Salah satu permasalahannya adalah Disharmoni peraturan perundang-undangan mengakibatkan terjadinya perbedaan penafsiran dalam pelaksanaannya; timbulnya ketidakpastian hukum; peraturan perundang-undangan tidak terlaksana secara efektif dan efisien, dan disfungsi hukum, Secara de yure disharmoni peraturan perundang - Undangan dibawah dengan peraturan perundang- undangan diatasnya merupakan bahan evaluasi. Tapi secara de facto, ada sejumlah Raperda berlandaskan pada aturan diluar tata urutan peraturan Perundangan.

Padahal didalam Pasal 7 ayat 2 Undang- Undang Nomor 12 Tahun 2011 menegaskan Kekuatan hukum Peraturan Perundang-undangan sesuai dengan hierarki yang ada dalam ayat 1.Dilanjut terkait Pasal 140 ayat (3) Undang- Undang Nomor 23 Tahun 2014 tentang Pembentukan Peraturan Perundang-Undangan sebagaimana telah mengalami perubahan yang kedua dalam Undang-Undang Republik Indonesia Nomor 9 Tahun 2015 Tentang Pemerintahan Daerah, menyebutkan bahwa Tata cara mempersiapkan rancangan Perda yang berasal dari Gubernur atau Bupati/Walikota diatur dengan Peraturan Presiden. Kemudian Pasal 141 ayat (2) Undang-Undang Pemerintah Daerah menyebutkan bahwa Ketentuan lebih lanjut mengenai tata cara mempersiapkan rancangan Perda diatur dalam Peraturan Tata Tertib DPRD.

Berdasarkan asas pembentukan peraturan perundang-undangan,maka Peraturan Menteri Dalam Negeri ini menyalahi asas kesesuaian antara jenis dan materi muatan, karena seharusnya substansi tersebut merupakan materi muatan Peraturan Presiden selaku bagian dari Hierarkisitas Tata Urutan Peraturan Perundang - Undangan dan materi muatan Peraturan Tata Tertib DPRD.
\end{abstract}

\section{Kata Kunci: Hukum Formil, Peraturan Daerah, dan Asas Hirarkisitas.}




\begin{abstract}
The regulation in the Regional Regulation is faced with the problem of how the Regional Regulation can regulate the affairs of authority in accordance with the characteristics of the region. But it does not conflict with the higher laws and regulations. One of the problems is Disharmony legislation resulting in differences in interpretation in its implementation; the emergence of legal uncertainty; Legislation is not carried out effectively and efficiently, and legal dysfunction, in a disharmonic manner, the rules and regulations - Invitation under the above laws and regulations is an evaluation material. But de facto, there are a number of draft regulations based on rules outside the order of the laws.

Whereas in Article 7 paragraph 2 of Act Number 12 of 2011 confirms the strength of the laws of the legislation in accordance with the hierarchy in paragraph 1. Continued related to Article 140 paragraph (3) of Law Number 23 of 2014 concerning the Establishment of Legislation as has undergone the second amendment to the Law of the Republic of Indonesia Number 9 of 2015 concerning Regional Government, states that the procedure for preparing a draft Regional Regulation from the Governor or Regent / Mayor is regulated by a Presidential Regulation. Then Article 141 paragraph (2) of the Law on Regional Government states that further Provisions concerning the procedure for preparing the Regional Regulation are regulated in the DPRD Rules of Procedure.

Based on the principle of the formation of laws and regulations, the Minister of Home Affairs's regulation violates the principle of conformity between types and materials of content, because the substance should be the material of the contents of the Presidential Regulation as part of the hierarchy of the Order of Regulations - Invitation and the contents of the DPRD Rules of Procedure.
\end{abstract}

\title{
Keywords: Formulary Law, Regional Regulation, and Hierarchical Principle.
}

\section{PENDAHULUAN}

Lebih dari satu dekade era reformasi luasnya urusan Pemerintah daerah dalam menjalankan roda pemerintahan di daerah masing-masing dirasa sangat signifikan, misalnya yaitu dalam pembentukan peraturan daerah (selanjutnya disebut dengan perda).

Hal tersebut berimplikasi pada peningkatan banyaknya produk-produk hukum daerah yang dibentuk. Namun sangat disayangkan tak jarang produk hukum daerah yang dihasilkan hanya menjadi dampak atau semangat dari implementasi otonomi daerah di Indonesia sehingga banyak produk hukum yang kurang efektif.

Prof. Isrok dari Universitas Brawijaya menjelaskan dengan
Mencontohkan bahwa perda yang "bermasalah"dapat menurunkan minat investor untuk berinvestasi di daerah baik itu secara langsung maupun tidak langsung. ${ }^{1}$ Sebenaranya Esensi dari otonomi daerah adalah memberikan kewenangan kepada daerah otonom untuk mengatur urusan yang menjadi kewenangannya berdasarkan karakteristik daerah masing-masing atau menampakan kearifan local (Local Wisdom). Namun

${ }^{1}$ Isrok, Korelasi Antara Perda Bermasalah Dengan Tingkat Investasi Di Daerah, Jurnal Hukum No.4, Volume 16, Fakultas Hukum Universitas Brawijaya, 2009 dalam https:// media.neliti.com/ media/ publications/ 35578-ID- urgensi- harmonisasidan- sinkronisasi- peraturan- daerah- dalampembentukan- peratura.pdf diakses pada tanggal 24 September 2017 
demikian, pengaturan tersebut tetap tidak diperkenankan bertentangan dengan peraturan perundang-undangan yang lebih tinggi dan kepentingan umum.

Berkenaan dengan hal tersebut, maka pengaturan dalam Perda dihadapkan pada persoalan bagaimana agar Perda dapat mengatur urusan kewenangan sesuai dengan karakteristik daerahnya. Namun tidak bertentangan dengan peraturan perundang-undangan yang lebih tinggi.

Hal ini menjadikan pemaknaan terhadap sinkronisasi dan harmonisasi peraturan menjadi sangat penting. Pengaturan mengenai peraturan daerah dalam beberapa Undang- Undang Republik Indonesiadan peraturan perundangundangan dapat mengakibatkan adanya perbedaan penafsiran atau interpretasi.

\section{PERMASALAHAN}

Menurut Novianto dalam Oka Mahendra, perbedaan penafsiran atau interpretasi atau disharmoni peraturan perundang-undangan akan mengakibatkan munculnya permasalahan di dalam implementasinya. Ada 6 (enam) faktor yang menyebabkan disharmoni sebagai berikut: ${ }^{2}$

1. Pembentukan dilakukan oleh lembaga yang berbeda dan sering dalam kurun waktu yang berbeda;Pejabat yang berwenang untuk membentuk peraturan perundang-undangan berganti-ganti baik karena dibatasi oleh masa jabatan, alih tugas atau penggantian;

2. Pendekatan sektoral dalam pembentukan peraturan perundang-

2 Oka Mahendra, Harmonisasi Peraturan Perundang -undangan, http:// www.djpp. depkumham. go. id/ htn-dan-puu/ 421-harmonisasiperaturan-perundang-undangan. dalam html dalam http:// perpustakaan.bappenas.go.id/ lontar/ file?file=digital /130881-[_Konten_]- Konten\% 20C9218.pdf diakses pada tanggal 24 September 2017 undangan lebih kuat dibanding pendekatan sistem;

3. Lemahnya koordinasi dalam proses pembentukan peraturan perundangundangan yang melibatkan berbagai instansi dan disiplin hukum ${ }^{3}$;

4. Akses masyarakat untuk berpartisipasi dalam proses pembentukan peraturan perundangundangan masih terbatas;

5. Belum mantapnya cara dan metode yang pasti, baku dan standar yang mengikat semua lembaga yang berwenang membuat peraturan perundang-undangan.

6. Disharmoni peraturan perundangundangan mengakibatkan: terjadinya perbedaan penafsiran dalam pelaksanaannya; timbulnya ketidakpastian hukum; peraturan perundang-undangan tidak terlaksana secara efektif danefisien, dan disfungsi hukum, artinya hukum tidak dapat berfungsi memberikan pedoman berperilaku kepada masyarakat, pengendalian sosial, penyelesaian sengketa dan sebagai sarana perubahan sosial secara tertib dan teratur. ${ }^{4}$

\footnotetext{
${ }^{3}$ Contoh Kementerian Dalam Negeri RI merasa memiliki kompetensi dalam memberikan advis terhadap Perda Tentang Organisasi Pemerintahan Daerah padahal sepatutnya Kementerian lain perlu diminta pendapatna terkait pemisahan, penggabungan atau penghilangan bidang- bidang dalam penyelenggaraan Pemerintahan di Daerah.

${ }^{4}$ Contoh dalam hal konsideran mengingat, sejumlah Lembaga penyelenggara menganjurkan perlu mencantumkan Peraturan Menteri kedalam aturan tersebut, tetapi hal ini menjadi perdebatan dari sejumlah lembaga penyelenggara lain mengingat adanya penamaan nomenklatur dalam aturan dimaksud adalah produk regeling yang ruang lingkup hanya kedalam instansi. Sehingga sampai saat ini tidak ada kepastian hukum atau sumber hukum baku untuk menerangkan sejauh mana kedudukan Peraturan Menteri misal dapat dijadikan konsideran.
} 


\section{PEMBAHASAN}

\section{A. Urgensi Harmonisasi Aturan}

Sebagai Perwujudan azas Legi Inferiori derogate Legi Superiori

Sinkronisasi adalah penyelarasan dan penyelerasian berbagai peraturan perundang-undangan yang terkait dengan peraturan perundang-undangan yang telah ada dan yang sedang disusun yang mengatur suatu bidang tertentu. Proses sinkronisasi peraturan bertujuan untuk melihat adanya keselarasan antara peraturan yang satu dengan peraturan lainnya. Sinkronisasi dilakukan baik secara vertikal dengan peraturan di atasnya maupun secara horizontal dengan peraturan yang setara. ${ }^{5}$ Adapun tujuan dari kegiatan sinkronisasi adalah untuk mewujudkan landasan pengaturan suatu bidang tertentu yang dapat memberikan kepastian hukum yang memadai bagi penyelenggaraan bidang tersebut secara efisien dan efektif.

Sinkronisasi peraturan perundangundangan dapat dilakukan dengan dua cara, yaitu:

a. Sinkronisasi Vertikal

Dilakukan dengan melihat apakah suatu peraturan perundang-undangan yang berlaku dalam suatu bidang tertentu tidak saling bertentangan antara satu dengan yang lain.

Di samping harus memperhatikan hierarki peraturan perundang-undangan, sinkronisasi vertikal harus juga diperhatikan kronologis tahun dan nomor penetapan peraturan perundang-undangan yang bersangkutan.

\section{b. Sinkronisasi Horizontal}

${ }^{5}$ http:// www.jombangkab.go.id/ index.php/ web/ entry/ sinkronisasi-peraturan-perundanganundangan-di-kabupaten-jombang-menghindariadanya-tumpah-tindih.html diakses pada tangal 27 September 2017
Dilakukan dengan melihat pada berbagai peraturan perundang-undangan yang sederajat dan mengatur bidang yang sama atau terkait. Sinkronisasi horizontal juga harus dilakukan secara kronologis, sesuai dengan urutan waktu ditetapkannya peraturan perundangan-undangan yang bersangkutan.

Secara umum, prosedur sinkronisasi diawali dengan inventarisasi, yaitu suatu kegiatan untuk mengetahui dan memperoleh data dan informasi tentang peraturan perundang-undangan terkait. Selanjutnya dilakukan analisa terhadap substansi.

Harmonisasi idealnya dilakukan pada saat perancangan peraturan perundang-undangan. Pengharmonisasian rancangan undang-undang mencakup 2 (dua) aspek sebagai berikut:

1. Pengharmonisasian materi muatan rancangan undang-undang dengan:

a. Pancasila;

b. Undang-Undang Dasar Negara Republik Indonesia Tahun 1945/harmonisasi vertikal;

c. Undang-undang/harmonisasi horizontal;

d. Asas-asas peraturan perundangundangan:

1) Asas pembentukan.

2) Asas materi muatan.

3) Asas-asas lain yang sesuai dengan bidang hukum rancangan undangundang yang bersangkutan.

2. Pengharmonisasian rancangan undang-undang dengan teknik penyusunan peraturan perundangundangan yang meliputi:

1) Kerangka peraturan perundangundangan;

2) Hal-hal khusus; 
3) Ragam bahasa;

4) Bentuk rancangan peraturan

Perundang - undang.

Pengharmonisasian dilakukan dengan cara sebagai berikut: ${ }^{6}$

1. Pastikan bahwa rancangan undangundang mencantumkan nilai-nilai filosofis Pancasila dan pasal-pasal rancangan undang-undang yang bersangkutan tidak bertentangan dengan nilai-nilai tersebut.

2. Pastikan bahwa pasal-pasal UndangUndang Dasar Negara Republik Indonesia Tahun 1945 yang memerintahkan pembentukannya telah dicantumkan dengan benar dan pastikan pula bahwa rancangan undang-undang telah selaras dengan prinsip-prinsip penyelenggaraan negara menurut Undang-Undang Dasar.

3. Gunakan istilah hukum atau pengertian hukum secara konsisten.

4. Teliti dengan seksama apakah materi muatan rancangan undang-undang telah serasi/selaras dengan undangundang lain terkait.

5. Pastikan bahwa asas-asas peraturan perundang-undangan baik asas pembentukan, asas materi muatan, maupun asas lain yang berkaitan dengan bidang hukum yang diatur dalam rancangan undang-undang, telah terakomodasikan dengan baik dalam rancangan undang-undang.

6. Pastikan bahwa pedoman teknik penyusunan peraturan perundang-

\footnotetext{
${ }^{6}$ Oka Mahendra, Harmonisasi Peraturan Perundang -undangan, http:// www.djpp. depkumham. go. id/ htn-dan-puu/ 421-harmonisasiperaturan-perundang-undangan. dalam html dalam http:// perpustakaan.bappenas.go.id/ lontar/ file?file=digital /130881-[_Konten_]- Konten\% 20C9218.pdf diakses pada tanggal 24 September 2017
}

undangan telah dipatuhi secara konsisten.

7. Pastikan bahwa bahasa yang digunakan dalam merumuskan norma dalam rancangan undang-undang telah sesuai dengan kaidah bahasa Indonesia yang baik dan benar serta mengunakan pilihan kata yang tepat, jelas dan pasti.

Pengharmonisasian rancangan undang-undang yang dilaksanakan secara cermat dan profesional akan menghasilkan rancangan undang-undang yang memenuhi syarat sebagai rancangan undang-undang yang baik. Ada 8 (delapan) kriteria hukum yang baik menurut Lon Fuller dalam Sirajuddin $\mathrm{dkk}^{7}$ sebagai berikut:

1. Hukum harus dituruti semua orang, termasuk oleh penguasa negara;

2. Hukum harus dipublikasikan;

3. Hukum harus berlaku ke depan, bukan berlaku surut;

4. Kaidah hukum harus ditulis secara jelas, sehingga dapat diketahui dan diterapkan secara benar;

5. Hukum harus menghindari diri dari kontradiksi-kontradiksi;

6. Hukum jangan mewajibkan sesuatu yang tidak mungkin dipenuhi;

7. Hukum harus bersifat konstan sehingga ada kepastian hukum. Tetapi hukum harus juga diubah jika situasi politik dan sosial telah berubah;

8. Tindakan para aparat pemerintah dan penegak hukum haruslah konsisten dengan hukum yang berlaku.

${ }^{7}$ Sirajuddin, Legislative Drafting Pelembagaan Metode Partisipatif Dalam Pembentukan Peraturan Perundang- Undagan, (Malang:Setara Press, 2015), hal 33-34. 


\section{B. Asas Peraturan Perundang- undangan}

Ketika terdapat dua atau lebih peraturan perundang-undangan yang mengatur mengenai hal yang sama, akan berlaku asas atau prinsip peraturan perundang-undangan. Setidaknya terdapat empat asas hukum terkait dengan peraturan perundang-undangan:

1. Lex superior derogat legi inferiori.

Peraturan perundang-undangan bertingkat lebih tinggi mengesampingkan peraturan perundang-undangan tingkat lebih rendah, kecuali apabila substansi peraturan perundang-undangan lebih tinggi mengatur hal-hal yang oleh undang-undang ditetapkan menjadi wewenang peraturan perundang-undangan tingkat lebih rendah.

\section{Lex specialis derogat legi generalis}

Asas ini mengandung makna, bahwa aturan hukum yang khusus akan mengesampingkan aturan hukum yang umum. Ada beberapa prinsip yang harus diperhatikan dalam asas Lex specialis derogat legi generalis:

a) Ketentuan-ketentuan yang didapati dalam aturan hukum umum tetap berlaku, kecuali yang diatur khusus dalam aturan hukum khusus tersebut.

b) Ketentuan-ketentuan lex specialis harus sederajat dengan ketentuanketentuan lex generalis (undangundang dengan undang-undang).

c) Ketentuan-ketentuan lex specialis harus berada dalam lingkungan hukum (rezim) yang sama dengan lex generalis. Kitab Undang-Undang Hukum Dagang dan Kitab UndangUndang Hukum Perdata sama-sama termasuk lingkungan hukum keperdataan.

3. Asas lex posterior derogat legi priori.
Aturan hukum yang lebih baru mengesampingkan atau meniadakan aturan hukum yang lama.Asas lex posterior derogat legi priori mewajibkan menggunakan hukum yang baru.

Asas ini pun memuat prinsip-prinsip:

a. Aturan hukum yang baru harus sederajat atau lebih tinggi dari aturan hukum yang lama;

b. Aturan hukum baru dan lama mengatur aspek yang sama.

Asas ini antara lain bermaksud mencegah dualisme yang dapat menimbulkan ketidak pastian hukum. Dengan adanya Asas Lex posterior derogat legi priori, ketentuan yang mengatur pencabutan suatu peraturan perundangundangan sebenarnya tidak begitu penting. Secara hukum, ketentuan lama yang serupa tidak akan berlaku lagi pada saat aturan hukum baru mulai berlaku. Maksud dari kegiatan sinkronisasi adalah agar substansi yang diatur dalam produk perundangundangan tidak tumpang tindih, saling melengkapi (suplementer), saling terkait, dan semakin rendah jenis pengaturannya maka semakin detail dan operasional materi muatannyaDari kutipan yang telah dipaparkan oleh Hafiz Andi Sadewo ,Merupakan suatu kenyataan bahwa pengharmonisasian peraturan perundang undangan dalam hal ini Perda sebagian orang dianggap tidak mempunyaiimplikasi yang signifikan terhadap pelaksanaan peraturan perundangundangansecara umum. Dengan demikian selama tidak terjadi masalah daripelaksanaan peraturan perundang-undangan tersebut, maka penyelenggara Negara tidak merasa memerlukan adanya suatu pengharmonisasian hukum.

Masalah baru dirasakan oleh penyelenggaranegara apabila dalam pelaksanaan perundang-undangan menemui kesulitan.Misalnya telah terjadi duplikasi 
antara peraturan perundang-undangan yangsederajat satu sama lain atau pertentangan dari sisi hierarki peraturan perundangundangan.Atas penjelasan tersebut tidak heran bahwa pihak yang dirugikansebenarnya ialah masyarakat itu sendiri sebagai pihak yang paling berkepentingandengan pembentukan peraturan perundang-undangan tersebut ${ }^{8}$.

\section{Konten Kearifan Lokal (Perda) Tidak Diperkenankan Bertentangan Pada Pasal 7 Ayat 1 Undang- Undang Nomor 12 Tahun 2011 Tentang Pembentukan Peraturan Perundang - Undangan.}

Esensi dari otonomi daerah adalah memberikan kewenangan kepada daerah otonom untuk mengatur urusan yang menjadi kewenangannya berdasarkan karakteristik daerah masing-masing. Namun demikian, pengaturan tersebut tetap tidak diperkenankan bertentangan dengan peraturan perundang-undangan yang lebih tinggi dan kepentingan umum. Peraturan Daerah sebagai produk hukum daerah merupakan sesuatu yang inherentdengan sistem Otonomi Daerah.Hal ini sebagai konsekuensi dari sistem Otonomi Daerah itu sendiri yang bersendikan kemandirian dan bukan merupakan suatu bentuk kebebasan suatusatuan pemerintahan yang merdeka.Kemandirian itu sendiri mengandung arti bahwa Daerahberhak mengatur dan mengurus urusan rumah tangga pemerintahannya sendiri. Kewenangan mengatur disini mengandung arti bahwa daerah berhak membuat

8 Direktorat Jenderal Peraturan PerundangUndangan, Panduan Praktis Memahami Perancangan Peraturan Daerah,Kementerian Hukum dan Hak Asasi Manusia RI, Jakarta, 2011, hlm 203-252

Nasional/Bappenas, Jakarta, 2005, hlm 4-5 dalam https:// media.neliti.com/ media/ publications/ 35578-ID- urgensi- harmonisasi- dan- sinkronisasiperaturan- daerah- dalam-pembentukan- peratura.pdf diakses pada tanggal 24 September 2017 keputusan hukum berupaperaturan perundang-undangan,keberadaan Peraturan Daerah menjadi sesuatu yang mutlak dalam mengatur urusanrumah tangga daerah, dalam wadah negara kesatuan yang tetap menempatkan hubunganPusat dan Daerah yang bersifat subordinat dan independen. Peraturan Daerah merupakankeputusan dalam arti luas, sebagai tujuan untuk mengatur hidup bersama, melindungi hak dankewajiban manusia dalam masyarakat, melindungi lembaga-lembaga sosial dalammasyarakat dan mejaga keselamatan dan tata tertib masyarakat di daerah yang bersangkutanatas dasar keadilan, untuk mencapai keseimbangan dan kesejahteraan umum. Secara substansial Peraturan Daerah mengatur urusan pemerintahan yang sangat luas, sejalan dengankehendak undangundang yang memberikan otonomi yang seluas-luasnya kepada daerah.Berkenaan dengan hal tersebut, maka pengaturan dalam Perda dihadapkan pada persoalan bagaimana agar Perda dapat mengatur urusan kewenangan sesuai dengan karakteristik daerahnya, namun tidak bertentangan dengan peraturan perundangundangan yang lebih tinggi'. Hal ini menjadikan pemaknaan terhadap sinkronisasi dan harmonisasi peraturan menjadi sangat penting.Sebagai bukti di Setiap provinsi di Indonesia yang memiliki karakteristik akar budaya yang cukup kuat misal Provinsi Bali, Yogyakarta, Aceh, Papua memiliki karakteristik tersendiri. Fungsi dari peraturan daerah itu sendiri adalah:

1. sebagai instrumen kebijakan untuk melaksanakan otonomi daerah dan tugas pembantuan sebagaimana amanat UUD

${ }^{9}$ Badan Pembinaan Hukum Nasional Kementrian Hukum Dan HAM RI dalam http://jurnal.untan.ac.id/index.php/nestor/article/down load/10250/9924. Diakses tanggal 29 September 2017 
NRI Tahun 1945 dan Undang-Undang tentangPemerintahan Daerah.

2. sebagai penampung kekhususan dan keragaman daerah, serta penyalur aspirasi

masyarakat di daerah. Namun, pengaturannya tetap dalam kerangka Negara KesatuanRepublik Indonesia yangg berlandaskan Pancasila dan UUD 1945.

3. sebagai alat pembangunan dalam meningkatkan kesejahteraan daerah.

4. sebagai peraturan pelaksanaan dari peraturan perundang-undangan yang lebih tinggidan Perda harus tunduk pada ketentuan hierarki peraturan perundangundangan.

\section{Kedudukan Peraturan Daerah} sebagaimana yang tercantum dalam UU No 12 Tahun 2011 harus dimaknai sebagai bentuk dari suatu derajat sistem peraturan perundang undangan yang berlaku. Dimana nomor urut satu merupakan derajat yang paling tinggi dari system peraturan perundang undangan yang berlaku begitu seterusnya. Dalam konteks Peraturan Daerah baik Provinsi maupun Kabupaten/ Kota, merupakan derajat yang terendah dari jenis peraturan perundang undangan yang berlaku, dengan demikian setiap peraturan daerah harus mengikuti apa yang telah digariskan oleh aturan yang lebih atas serta tidak boleh bertentangan.

Analisis terhadap sinkronisasi dan harmonisasi pengaturan mengenai Peraturan Daerah menarik untuk dilakukan. Selain melalui kajian normatif, sinkronisasi peraturan antara peraturan perundangundangan yang lebih rendah terhadap peraturan yang lebih tinggi. Dalam proses pembentukannya, Perda perlu melalui suatu prosedur awal sebagai tindakan pencegahan dari tidak atau kurang berdaya gunanya suatu produk hukum yang dibentuk dikemudian hari, upaya tersebut dilakukan dengan melakukan pengkajian atas rancangan perda melalui proses yang disebut denganharmonisasi peraturan perundang-undangan (lihat pasal 58 ayat (1) dan (2) Undang- Undang Republik IndonesiaNomor 12 tahun 2011 tentang Pembentukan Peraturan Perundangundangan) Permasalahan di Daerah adalah dalam pelaksanaan harmonisasi dan sinkronisasi peraturan perundangundangankhususnya Peraturan daerah, belum terdapat aturan yang jelas dan baku dalampelaksanaan harmonisasi yang mengatur khusus dan spesifik mengenai petunjukharmonisasi peraturan perundangundangan di tingkat daerah sehingga tidakmenimbulkan perbedaan interpretasi mengenai harmonisasi perundang-undangan yang dijalankan di daerah ${ }^{10}$.

Sebagai contoh terdapat PerdaPerdaProvinsi, Kota dan Kabupaten di Kalimantan Timur yang yang saat ini dianggap keadaan disharmonis di Provinsi ini adalah ${ }^{11}$ :

${ }^{10}$ Penulis berpendapat, kondisi UndangUndang Nomor 12 Tahun 2011 memang belum memiliki metode dan landasan yang ajeg untuk memberikan kepastian pada produk hukum daerah apakah sudah memiliki sinergisitas dengan Peraturan yang ada diatasnya atau belum, oleh karena itu ditahun 2015 Kementerian Dalam Negeri Republik Indonesia selaku Lembaga Penyelenggara Negara bertanggung Jawab $\mathrm{t}$ urusan Pemeritahan Daerah berinisiasi membuat Peraturan Dalam Negeri perihal menjabarkan metode mensinergikan aturan daerah dengan aturan diatasnya, Persoalannya adalah jika ada sejumlah Perundang Undangan oleh Lembaga Peyelenggara lain dengan konten yang berlainan pula prosedurnya, apakah Pemerintah Daerah mengikuti petunjuk dari Kementerian Dalam Negeri atau lembaga public lainnya, contoh Lihat Pasal 88 Peraturan Dalam Negeri Republik Indonesia Nomor 80 Tahun 2015 Tentang Pembentukan Produk Daerah terkait perlunya sinergisitas, harmonisasi dan singkronisasi dengan cara fasilitasi hanya melalui ke Kementerian Dalam Negeri RI, Jika konten dalam Perda bertentangan dengan aturan Kementerian Dalam Negeri, Bagaimana dengan Kementerian lain? 11 Dianggap disharmonisasi karena Pemerintahan Daerah Kalimantan Timur melihat materi muatan Perda yang ada belum memiliki aturan teknis yang mengkomodir kebutuhan daerah, kemudian Pemerintah Pusat membuat sejumlah 
1. Perda Tentang Pembentukan Peraturan Daerah

2. Perda Tentang Pengelolaan Barang Milik Daerah (Provinsi dan Kabupaten/ Kota

3. Penyelenggaraan Jalan Umum dan Jalan Khusus Untuk Kegiatan Pengangkutan Batubara dan Kelapa Sawit.

4. Tentang Pengelolaan Barang Milik Daerah Provinsi Kaltim

Perda Perda yang dianggap sudah melalui Singkronisasi dan Harmonisasi antara lain ${ }^{12}$ :

1. Perda tentang Perlindungan Masyarakat Hukum Adat (Provinsi)

2. Perda Fasilitasi dan Pencegahan Narkotika

3. Perda tentang Organisasi Perangkat Daerah

Letak atau posisi dari harmonisasi dalam pembentukan peraturan perundangundangan berdasarkan Undang- Undang Republik Indonesia Republik Indonesia Nomor 12 Tahun 2011 tentang Pembentukan Peraturan PerundangUndangan memang belum baku dan jelas ,belum memuat aspek-aspek pengaturan yang seharusnya diharmoniskan pada suatu rancangan peraturan perundang-undangan (termasuk salah satu diantaranya perda), oleh karena tidak diatur secara rinci atau mendetail dalam suatu bab yangmengatur secara khusus tentang harmonisasi peraturan perundang-undangan. Hal tersebut dapat dilihat dari dalam bab-bab

Peraturan Setingkat Menteri yang mengakomodir kebutuhan yang dimaksud. Sehingga Peraturan Menteri untuk saat ini menjadi sumber hukum dalam mengisi konten serta sumber hukum formal dari Perda lihat dalam Program Pembentukan Perda Tahun 2017.

12 Perda tersebut sudah melalui tahapan Pengawasan Preventif vertical berupa harmonisasi, singkronisasi dan fasilitasi kepada Kementerian Dalam Negeri (lihat pasal 88 Permendagri Nomor 50 Tahun 2015 tentang Pembetukan Produk Hukum Daerah).
Undang- Undang Republik Indonesia Nomor 12 Tahun 2011 tentang Pembentukan Peraturan PerundangUndangan tersebut yang tidak memuat pengaturan lebih luas dan mendalam mengenai harmonisasi dan sinkronisasi. Salah satu bentuk dari penyelarasan atau penyesuaian perda dengan peraturan perundang-undangan lainnya yaitu dengan melakukan pembatalan perda di suatu daerah. Bentuk pembatalan terhadap perda tersebut dapat berupa pembatalan perda secara keseluruhan atau pembatalan atas beberapa pasal dan/atau ayat suatu Perda.

Bentuk pembatalan yang telah dijelaskan sebelumnya merupakan salah satubentuk pengujian oleh pemerintah. Bentuk dari legal norm control mechanism emudian dapat dibedakan kedalam 2 (dua) jenis pengendalian norma hukumyaitu oleh lembaga kehakiman (pengadilan/yudisial) dan Pemerintah Pusat yaitu:

1. Pengujian perda oleh lembaga kehakiman/Judicial review

Pengertian judicial review itu sendiri adalah pengujian peraturan perundangundangantertentu oleh hakim (yudikatif), hal ini berarti hak atau kewenanganmenguji (toetsingrecht) dimiliki oleh hakim. Pengujian tersebut dilakukanterhadap suatu ketentuan peraturan perundangundangan terhadap peraturanperundang-undangan yang lebih tinggi atau terhadap konstitusi sebagai hukumtertinggi, artinya judicial review dapat dimiliki oleh hakim di semua tingkat, ataudiberikan secara terpusat kepada Mahkamah Agung atau Mahkamah Konstitusi $^{13}$

13 Deni Daryatno, Tinjauan Yuridis tentang Legalitas Executive Review Terhadap Peraturan Daerah dalam https:// media.neliti.com/ media/ publications/ 35578-ID- urgensi- harmonisasi- dan- 
2. Pengujian Perda oleh Pemerintah (Executive preview/ review)

Bentuk executive review/ preview lazim disebut sebagai pengawasan. Pengawasan perda tersebut memiliki 2 (dua) model dalam pelaksanaannya diIndonesia.Pengawasan tersebut terdiri atas pengawasan preventif (pencegahan)dan pengawasan represif (penindakan).Pengawasan represif disebut denganexecutive review dan pengawasan preventif yang dilakukan lazim disebut denganexecutive preview. Tidak tertutup kemungkinan kedua jenis pengawasan tersebutditerapkan pada suatu perda yang akan diberlakukan ataupun yang telah berlakumengikat masyarakat.

D. Analisa Terhadap Singkronisasi dan Harmonisasi Regulasi di Indonesia Berlandaskan Pada Produk Hukum lain di Luar Pasal 7 ayat 1 Undang- Undang Nomor 12 Tahun 2011.

Secara vertikal, analisis sinkronisasi pengaturan mengenai peraturan daerah akan dilakukan antara Undang- Undang Republik Indonesia dengan Peraturan Menteri Dalam Negeri Nomor 80 Tahun 2015 tentang Pembentukan Produk Hukum Daerah. Berdasarkan Peraturan Menteri Dalam Negeri tersebut diatur mengenai ketentuan formil pembentukan Perda secara rinci mulai dari perencanaan, penyusunan, dan pembahasan. Sementara UndangUndang Republik Indonesia tentang Pemerintahan Daerah tidak mengatur tahapan pembentukan Perda secara rinci. Berdasarkan Peraturan Menteri Dalam Negeri, penyusunan Prolegda sebagai bagian dari tahapan perencanaan

sinkronisasi- peraturan- daerah- dalam-pembentukanperatura.pdf diakses pada tanggal 24 September 2017 dilaksanakan oleh pemerintah daerah dan DPRD. Pada intinya mekanisme pelaksanaan penyusunan prolegda tersebut identik dengan penyusunan Program Legislasi Nasional (prolegnas).

Pada tahapan penyusunan, Permendagri nomor 80 Tahun 2015 Tentang Pembentukan Produk Hukum Daerah mengatur mekanisme persiapan penyusunan perda di Pemerintah Daerah dan Persiapan Penyusunan Perda di lingkungan DPRD. Jika diselaraskan dengan pengaturan di tingkat nasional, persiapan penyusunan di lingkungan eksekutif memang merupakan domain eksekutif, namun persiapan penyusunan peraturan perundang-undangan di legislatif merupakan domain legislatif dan diatur dalam peraturan lembaga legislatif (DPR).

Peraturan Menteri Dalam Negeri juga mengatur mekanisme pembahasan Perda antara DPRD dan Kepala Daerah. Normanorma yang terdapat di dalam Permendagri tersebut identik dengan bagaimana pembahasan suatu Rancangan UndangUndang Republik Indonesiaantara DPR dan Presiden, termasuk tingkat-tingkat pembahasannya .Salah satu permasalahan pokok dari Peraturan Menteri Dalam Negeri Nomor 80 Tahun 2015 tentang Pembentukan Produk Hukum Daerah adalah tidak ada amanat dalam UndangUndang Republik Indonesia agar penjabaran pengaturan mengenai Pembentukan Peraturan Daerah diatur dalam Peraturan Menteri Dalam Negeri Nomor 80 Tahun 2015 Tentang Pembentukan Produk Hukum Daerah lagi pula Produk hukum ini bukan kategori memiliki kekuatan hukum sebagai bagian dari hierarkisitas dalam Tata Urutan Peraturan Perundang- Undangan saat ini dan landasan hukum. Tidak bisa dipungkiri dari masa ke masa Peraturan Menteri selalu menjadi bahan yang selalu diperdebatkan 
kehadirannya dalam Tata Urutan Perundang- Undangan namun menjadi suatu persoalan jika Peraturan Menteri menjadi bagian dari alat singkronisasi aturan diabawahnya khusunya Perda. Berikut bukti inkonsistensi Tata Urutan Perundang-undangan dari Masa ke Masa terkait dimasukan atau tidaknya Peraturan Menteri bagian dari Tata Urutan Perundang- Undangan ${ }^{14}$ :

1. Era Kemerdekaan (18 Agustus 1945 27 Desember 1949)

- Undang-Undang Dasar 1945

- Undang-undang / Peraturan Pemerintah Pengganti Undangundang

- Peraturan Pemerintah

- Peraturan Menteri

2. Era Republik Indonesia Serikat (27 Desember 1949 - 17 Agustus 1950)

- Konstitusi Republik Indonesia Serikat 1949

- Undang-undang / Undangundang Darurat

- Peraturan Pemerintah

3. Era Berlakunya UUDS 1950 (17 Agustus 1950 - 05 Juli 1959)

- Undang-Undang Dasar Sementara Tahun 1950

- Undang-undang / Undangundang Darurat

- Peraturan Pemerintah

- Keputusan Presiden

- Peraturan Menteri

- Keputusan Menteri

- Peraturan-peraturan Tingkat Daerah

4. Era Berlakunya Dekrit 05 Juli 1959

- Undang-Undang Dasar 1945

- Ketentuan Majelis Permusyawaratan Rakyat Sementara

\footnotetext{
14 Sirajuddin dkk, Legislative Drafting Pelembagaan Metode Partisipatif Dalam Pembentukan Peraturan Perundang- Undagan, (Malang:Setara Press, 2015)hal 47
}

- Undang-undang / Peraturan Pemerintah Pengganti Undangundang

- Peraturan Pemerintah / Peraturan Presiden

- Keputusan Presiden

- Peraturan Menteri

- Keputusan Menteri

Catatan:

a. Dekrit 05 Juli 1959 yang mengakhiri pemberlakuan Undang-Undang Dasar Sementara Tahun 1950 dikukuhkan secara aklamasi oleh Dewan Perwakilan Rakyat pada tanggal 22 Juli 1959 (sebagaimana tercantum dalam Lembaran Negara No. 75 tahun 1959)

b. Pada tanggal 26 Nopember 1959 Presiden Soekarno pernah mengirim Surat Presiden kepada Ketua DPR No. 3639/HK/1959 yang melatarbelakangi pembentukan Penetapan Presiden (Penpres) dan Peraturan Presiden (Perpres).

5. Era Berlakunya Tap. MPRS No. XX/MPRS/1966 Tentang Memorandum DPR-GR Mengenai Sumber Tertib Hukum Republik Indonesia (Jo. Tap. MPR No. V/MPR/1978)

- Undang-Undang Dasar 1945

- Ketetapan Majelis Permusyawaratan Rakyat

- Undang-undang / Peraturan Pemerintah Pengganti Undangundang

- Peraturan Pemerintah

- Keputusan Presiden

- Instruksi Presiden

- Peraturan Pelaksana Lainnya: (seperti Keputusan Menteri dan Instruksi Menteri)

6. Era Berlakunya Tap. MPR No. III/MPR/2000 Tentang Sumber Hukum dan Tata Urutan Peraturan Perundang-undangan 
- Undang-Undang Dasar 1945

- Ketetapan Majelis Permusyawaratan Rakyat

- Undang-undang

- Peraturan Pemerintah Pengganti Undang-undang

- Peraturan Pemerintah

- Keputusan Presiden

- Peraturan Daerah

7. Era Berlakunya Pasal 7 UU. No. 10 Tahun 2004 Tentang Pembentukan Peraturan Perundang-undangan

- Undang-Undang Dasar Negara Republik Indonesia 1945

- Undang-undang / Peraturan Pemerintah Pengganti Undangundang

- Peraturan Pemerintah

- Peraturan Presiden

- Peraturan Daerah

8. Jenis dan hierarki Peraturan Perundang-undangan menurut Pasal 7 ayat 1 Undang- Undang Nomor 12 Tahun 2011 Pembentukan Peraturan Perundang Undangan terdiri atas:

- Undang-Undang Dasar Negara Republik Indonesia Tahun 1945;

- Ketetapan Majelis Permusyawaratan Rakyat;

- Undang-Undang/Peraturan Pemerintah Pengganti UndangUndang;

- Peraturan Pemerintah;

- Peraturan Presiden;

- Peraturan Daerah Provinsi; dan

- Peraturan Daerah Kabupaten/Kota Didalam Pasal 7 ayat 2 UndangUndang Nomor 12 Tahun 2011 menegaskan Kekuatan hukum Peraturan Perundang-undangan sesuai dengan hierarki yang ada dalam ayat 1.Dilanjut terkait Pasal 140 ayat (3) Undang- Undang Nomor 23 Tahun 2014 tentang Pembentukan Peraturan Perundang-Undangan sebagaimana telah mengalami perubahan yang kedua dalam Undang-Undang Republik Indonesia Nomor 9 Tahun 2015 Tentang Pemerintahan Daerah, menyebutkan bahwa Tata cara mempersiapkan rancangan Perda yang berasal dari Gubernur atau Bupati/Walikota diatur dengan Peraturan Presiden. Kemudian Pasal 141 ayat (2) UndangUndang Pemerintah Daerah menyebutkan bahwa Ketentuan lebih lanjut mengenai tata cara mempersiapkan rancangan Perda diatur dalam Peraturan Tata Tertib DPRD. Berdasarkan asas pembentukan peraturan perundang-undangan,maka Peraturan Menteri Dalam Negeri ini menyalahi asas kesesuaian antara jenis dan materi muatan, karena seharusnya substansi tersebut merupakan materi muatan Peraturan Presiden selaku bagian dari Hierarkisitas Tata Urutan Peraturan PerundangUndanngan dan materi muatan Peraturan Tata Tertib DPRD.

Salah satu contoh bahwa Peraturan Dalam Negeri Nomor 80 Tahun 2015 dianggap bekerja tidak sesuai pada kedudukannya sebagaialat untuk sinkronisasi dan harmonisasi dapat dilihat pada pasal 8 Undang- Undang Nomor 12 Tahun 2011 Tentang Pembentukan Peraturan Perundang- Undangan :

“1. Jenis Peraturan Perundang-undangan selain sebagaimana dimaksud dalam Pasal 7 ayat (1) mencakup peraturan yang ditetapkan oleh Majelis Permusyawaratan Rakyat, Dewan Perwakilan Rakyat, Dewan Perwakilan Daerah, Mahkamah Agung, Mahkamah Konstitusi, Badan Pemeriksa Keuangan, Komisi Yudisial, Bank Indonesia, Menteri, badan, lembaga, atau komisi yang setingkat yang dibentuk dengan Undang- Undang Republik Indonesiaatau Pemerintah atas perintah Undang-Undang, Dewan 
Perwakilan Rakyat Daerah Provinsi, Gubernur, Dewan Perwakilan Rakyat Daerah Kabupaten/Kota, Bupati/Walikota, Kepala Desa atau yang setingkat.

d) Peraturan Perundang-undangan sebagaimana dimaksud pada ayat (1) diakui keberadaannya dan mempunyai kekuatan hukum mengikat sepanjang diperintahkan oleh Peraturan Perundang-undangan yang lebih tinggi atau dibentuk berdasarkan kewenangan."

$$
\text { Penjelasan }
$$$$
\text { Ayat } 1
$$

"Yang dimaksud dengan "Peraturan Menteri" adalah peraturan yang ditetapkan oleh menteri berdasarkan materi muatan dalam rangka penyelenggaraan urusan tertentu dalam pemerintahan.

Ayat (2)

Yang dimaksu dengan "berdasarkan kewenangan" adalah penyelenggaraan urusan tertentu pemerintahan sesuai dengan ketentuan Peraturan Perundang-undangan."

Sebagaimana diamanatkan oleh Undang- Undang Republik Indonesia Pemerintahan Daerah. Hal yang sama juga diamanatkan oleh Undang- Undang Nomor 12 tahun 2011 Tentang Pembentukan Peraturan Perundang- Undangan, yaitu dengan Peraturan Presiden dan Peraturan DPRD, bukan Peraturan Menteri Dalam Negeri. Dari penjabaran sisi normative sudah jelas bahwa Peraturan Menteri bukanlah sebagai landasah hukum yang tepat untuk alat untuk singkronisasi dan harmonisasi. Dari ketentuan ini dapat dijelaskan bahwa peraturan menteri lahir karena urusan tertentu dalam pemerintahan yakni urusan -urusan yang telah menjadi urusan kementerian itu sendiri dan urusan yang telah ditetapkan oleh peraturan perundang-undangan baik undang undang, peraturan pemerintah maupun peraturan presiden. Meskipun demikian tidak semua kementerian mempunyai kewenangan untuk membentuk peraturan menteri, hanya menteri- menter iyang memimpin suatu lembaga saja yang berhak untuk mengeluarkan Peraturan Menteri, tidak seperti halnya menteri koordinator karena sifatnya hanya kordinasi saja antar kementerian. Menurut O.Hood Philips yang pendapatnya dikutip oleh Anna Erliana menyatakan Baik menteri, pemerintah daerah dan badan-badan publik lainnya, hanya sah melaksanakan wewenangnya dalam batas-batas yang diberikan undangundang kepadamereka. Keputusan yang dibuat mungkin melebihi wewenang dan menjadi ultra vires karena badan administrasi melakukan transaksi dengan persoalan diluar wewenangnya ini disebut substantif ultra vires, atau karena gagal mengikuti prosedur yang ditentukan maka tindakannya disebut prosedural ultra vires. ${ }^{15}$

Selanjutnya di dalam Pasal 7 ayat 1 Undang- Undang Nomor 12 Tahun 2011 secara jelas terlihat posisi atau kedudukan Peraturan Menteri tidak dicantumkan dalam Hirarkhi Peraturan Perundangundangan, sehingga tidak dapat dipastikan secara normatif posisi peraturan menteri lebih tinggi atau lebih rendah dari peraturan daerah, baik provinsi maupun kabupaten/ kota ,sedangkan penjenjangan antara peraturan daerah provinsi dengan kabupaten/ kota hirarkhinya cukup jelas. Makna hirarkhi itu sendiri tidak lain adalah penjenjangan setiap jenis PeraturanPerundang-undangan yang didasarkan pada asas bahwa Peraturan Perundang-undangan yang lebih rendah tidak boleh bertentangan dengan PeraturanPerundang-undangan yang lebih tinggi.

\footnotetext{
${ }^{15}$ http://jurnal.untan.ac.id/index.php/nestor/artic le/download/10250/9924.Diakses tanggal 29 September 2017
} 
E. Kedudukan Peraturan Menteri Dikaitkan Ilmu PerundangUndangan

Menurut B. Hestu Cipto Handoyo ${ }^{16}$

Ilmu Perundang-undangan merupakan cabang dari ilmu hukum yang secara khusus objek kajiannya adalah meneliti tentang gejala peraturan peraturan perundang-undangan yakni setiap keputusan tertulis yg dikeluarkan oleh pejabat yang berwenang untuk mengatur tingkah laku manusia yang bersifat dan berlaku mengikat umum.

Ciri-ciri peraturan perundang-undangan :

- Peraturan perUUan berupa keputusan tertulis, jadi mempunyai bentuk atau format tertentu.

- Dibentuk, ditetapkan dan dikeluarkan oleh pejabat yang berwenang, baik ditingkat pusat maupun di di tingkat daerah. Pejabat yang berwenang yang dimaksud adalah pejabat yang ditetapkan berdasarkan ketentuan yang berlaku baik berdasarkan atribusi maupun delegasi.

- Perturan PerUUan tersebut berisi aturan pola tingkah laku.

- $\quad$ Peraturan PerUUanb mengikat secara umum umum, tidak ditujukan kepada seseorang atau individu tertentu (tidak bersifat individual).

- Peraturan perUUan berlaku secara terus menerus (dauerhafing) sampai diubah, dicabut atau digantikan dengan peraturan perUUan yang baru.

a. Kelebihan Dan Kelemahan Peraturan Perundang-Undangan ${ }^{17}$ :

- Kelebihan peraturan PerUUan (hukum tertulis) :

1. Mudah dikenali, diketemukan kembali maupun ditelusuri.

${ }^{16}$ B. Hestu Cipto Handoyo, Prinsip- Prinsip Legal Drafting dan Desain Naskah Akademik (Yogyakarta:Universitas Atma Jaya, 2008).hal 5

${ }^{17} \mathrm{Ibid}$. hal 56-57
2. Lebih memberikan kepastian hukum

3. Memungkinkan untuk diperiksa dan diuji

4. Pembentukan dan pengembangannya dapat direncanakan.

b. Kelemahan Peraturan PerUUan (hukum tertulis):

1. Terkesan kaku

2. Kurang lengkap.

Selain itu juga dalam rangka menyusun dan membentuk peraturan perundang- undangan selain perlunya penguasaan ilmu perundang-undangan seorang legal drafter juga harus memperhatikan norma ataukaidah hukum sebagai dasar pembentukan per UndangUndangan tersebut.Kaidah atau norma hukum pada pokoknya dapat diartikan adalah pengambilan keputusan yang ditetapkan oleh fungsi-fungsi kekuasaan negara yang mengikat subyek hukum dengan hak-hak dan kewajiban hukum yg berupa larangan, keharusan maupun kebolehan.Produk pengambilan keputusan tersebut dapat dibedakan dengan tiga istilah yaitu $^{18}$ :

1. Pengaturan yg menghasilkan peraturan (regels)

2. Penetapan yg menghasilkan ketetapan atau keputusan (beschickkings)

3. Penghakiman atau pengadilan yang menghasilkan putusan (vonis).

c. Bentuk-Bentuk Norma Hukum :

- Umum dan individual: norma ini dilihat dari sasaran atau subyek yang dituju. Individu, beberapa orang atau sekelompok orang tertentu

- Abstrak dan konkrit: Abstrak atau konkritnya suatu norma ditentukan

18 Rahmat Trijono, Dasar- Dasar Ilmu Pengetahuan Perundang- Undangan,(Jakarta,Papas Sinar Sinanti,2014) hal 37 
oleh bentuk perbuatan yang diatur, mujarad (tak berwujud) atau nyata.

- Einmahlig dan dauerhaftig: Norma hukum ini dapat dilihat dari masa berlakunya. Einmahlig (berlaku sekali selesai) dan dauerhafting secara terus menerus sampai ada peraturan baru yang menggantikannya. Menurut D.W.P. Ruiter, dalam kepustakaan di Eropa Kontinental yang dimaksud peraturan perundang-undangan yaitu mengandung 3 unsur :

a. Norma hukum (rechtnorm)

b. Berlaku ke luar (naar buiten werken) dan

c. Bersifat umum dalam arti luas (algemeenheid in ruime zin). ${ }^{19}$

d. Pihak Yang Dikenakan Suatu Norma

Ruiter berpendapat bahwa didalam peraturan perundang-undangan tradisi yang hendak membatasi berlakunya norma hanya bagi mereka yang tidak termasuk dalam organisasi pemerintahan. Norma hanya ditujukan kepada rakyat, baik dalam hubungan antar sesama maupun antara rakyat dan pemerin tah. Norma yang mengatur hubungan antar bagian-bagian organisasi pemerintahan dianggap bukan norma yang sebenarnya dan hanya dianggap norma organisasi. Oleh karena itu norma hukum dalam peraturan perundangundangan selalu disebut "berlaku ke luar"20

Mengenai berlakunya norma Ruiter Sebagaimana dikutib oleh Maria Farida Indrati $S$ berpendapat:

"Bahwa di dalam peraturan perundang-undangan terdapat tradisi yang hendak membatasi berlakunya norma hanya bagi mereka yang tidak termasuk dalam organisasi pemerintahan. Norma hanya

19 Sirajuddin dkk, Legislative Drafting Pelembagaan Metode Partisipatif Dalam Pembentukan Peraturan Perundang- Undagan, (Malang:Setara Press, 2015)hal 39-42

${ }^{20} \mathrm{Ibid}$ ditujukan kepada rakyat, baik dalam hubungan sesamanya, maupun antara rakyat dan pemerintah. Norma yangmengatur hubungan antar bagian-bagian organisasi pemerintahan dianggap bukan norma yang sebenarnya, dan hanya dianggap norma organisasi, oleh karena itu, norma hukum dalam peraturan perundang-undangan selalu disebut "berlaku keluar". ${ }^{21}$

Lembaga atau pejabat yang berwenang, baik ditingkat pusat atau di tingkat daerah yang dibentuk berdasarkan kewenangan Perundang Undangan, baik bersifat atribusi maupun bersifat delegasi. Undang-Undang Dasar 1945 Perubahan, Konstitusi Indonesia menyebut lembagalembaga yang memiliki kewenangan untuk membentuk peraturan perundang-undangan meliputi:

a. Majelis Permusyawaratan Rakyat (MPR) yang berwenang mengubah danmenetapkan Undang-Undang Dasar.

b. Dewan Perwakilan Rakyat (DPR) yang memegang kekuasaan membentukUndang-Undang dengan persetujuan bersama Presiden.

c. Presiden yang berhak mengajukan rancangan Undang-Undang kepada DPR, menetapkan Peraturan Pemerintah Pengganti UndangUndang,Peraturan Pemerintah,

d. Pemerintahan Daerah yang berhak menetapkan Peraturan Daerah dan Peraturan Lain.

Melihat pengaturan dalam batang tubuh UUD 1945 perubahan, UndangUndang Nomor 12 Tahun 2011 serta Undang Nomor 23 Tahun 2014 sebagaimana telah mengalami Perubahan yang kedua Undang- Undang Nomor 9

21 Maria Farida Indrati S, Ilmu Perundangundangan, Jenis, Fungsi, dan Materi Muatan, op.cit.hlm.36 dalam http:// jurnal.untan.ac.id / index.php/ nestor/ article/ download/ 10250/ 9924 .Diakses tanggal 29 September 2017 
Tahun 2015 Tentang Pemerintahan Daerah, maka dapat disimpulkan bahwa Hukum Positif Indonesia tidak menyinggung sama sekali dan tidak memberikan kewenangan atribusi maupun delegasi kepada menteri untuk membentuk Peraturan Menteri. Selain itu Peraturan Menteri pun bukanlah aturan berjenis "regeling murni" ,karena aturan tersebut dibuat untuk hal tertentu oleh instansi (tidak berlaku keluar) dan bidang tertentu(khusus).Sehingga Peraturan Menteri tidak dapat dikatakan sebagai landasan hukum dan tidak perlunya dicantumkan kedalam konsideran mengingat dalam aturan dibawahnya kecuali aturan yang berjenis ketetapan.

\section{PENUTUP KESIMPULAN}

Bahwa perlunya Singkornisasi dan Harmonisasi dari Peraturan PerundangUndangan diatas kepada aturan dibawah disesuaikan dengan amanah Peraturan Perundang- Undangan yang ada, misal Peraturan Daerah sepatutnya mengacu pada Peraturan Presiden, hal ini sebagai konsistensi Penyelenggara Negara dalam menegakkan asas Negara hukum.

bahwa peraturan menteri merupakan suatu peraturan perundangan-undangan tetapi tidak mempunyai kategori dan levelitas dalam hierarkisitas Peraturan Peundang- Undangan yang tertuang dalam Pasal 7 ayat 1 Undang- Undang Nomor 12 Tahun 2011 , sehinggamemasukkan peraturan menteri di dalam konsiderans "mengingat" dalam suatuperaturan daerah dianggap kurang tepat dalam normatif yang berakibat tidak ada kepastian hukum peraturan daerah tersebut.

\section{DAFTAR PUSTAKA}

\section{Buku/Literatur:}

Sirajuddin dkk, Legislative Drafting Pelembagaan Metode Partisipatif Dalam Pembentukan Peraturan Perundang- Undagan, (Malang: Setara Press, 2015),

B. Hestu Cipto Handoyo, Prinsip- Prinsip Legal Drafting dan Desain Naskah Akademik (Yogyakarta: Universitas Atma Jaya, 2008).
Rahmat Trijono, Dasar- Dasar Ilmu Pengetahuan Perundang- Undangan,(Jakarta ,Papas Sinar Sinanti,2014)

\section{Perundang-Undangan:}

Undang-Undang Negara Republik Indonesia Tahun 1945

Undang-Undang Nomor 12 Tahun 2011 Tentang Pembentukan Peraturan Perundang- Undangan

Undang-Undang Republik Indonesia Nomor 9 Tahun 2015 Tentang Perubahan Kedua atas UndangUndang Nomor 23 Tahun 2014 tentang Pemerintahan Daerah

Peraturan Menteri Dalam Negeri Republik Indonesia Nomor 80 Tahun 2015 Tentang Pembentukan Produk Hukum Daerah

\section{Link/Elektronik Literatur}

Isrok, Korelasi Antara Perda Bermasalah Dengan Tingkat Investasi Di Daerah, Jurnal Hukum No.4, Volume 16, Fakultas Hukum Universitas Brawijaya, 2009 dalam https:// 
media.neliti.com/ media/ publications/ 35578-ID- urgensiharmonisasi- dan- sinkronisasiperaturan- daerah- dalampembentukan- peratura.pdf diakses pada tanggal 24 September 2017

Oka Mahendra, Harmonisasi Peraturan Perundang -undangan, http:// www.djpp. depkumham. go. id/ htndan-puu/ 421-harmonisasiperaturan-perundang-undangan.

dalam html dalam http:// perpustakaan.bappenas.go.id/ lontar/ file?file=digital /130881-[_Konten_]Konten\% 20C9218.pdf diakses pada tanggal 24 September 2017

http://www.jombangkab.go.id/index.php/ web/ entry/ sinkronisasi-peraturanperundangan-undangan-dikabupatenjombang-menghindari-adanya tumpah-tindih.html diakses pada tangal 27 September 2017

Direktorat Jenderal Peraturan PerundangUndangan, Panduan Praktis Memahami Perancangan Peraturan Daerah,Kementerian Hukum dan Hak Asasi Manusia RI, Jakarta, 2011, hlm 203-252

Nasional/Bappenas, Jakarta, 2005, hlm 4-5 dalam https:// media.neliti.com/ media/ publications/ 35578-IDurgensi- harmonisasi- dansinkronisasi- peraturan- daerahdalam-pembentukan- peratura.pdf diakses pada tanggal 24 September 2017

Badan Pembinaan Hukum Nasional Kementrian Hukum Dan HAM RI dalamhttp://jurnal.untan.ac.id/index.p hp/nestor/article/download/10250/99
24. Diakses tanggal 29 September 2017

Maria Farida Indrati S, Ilmu Perundangundangan, Jenis, Fungsi, dan Materi Muatan, op.cit.hlm.36 dalam http:// jurnal.untan.ac.id / index.php/ nestor/ article/ download/ 10250/ 9924 .Diakses tanggal 29 September 2017 